\title{
128 自動車の音質評価データベースの作成
}

\section{Creation of Automotive Sound Quality Evaluation Database}

\author{
○非 星野 博之（豊田中央研究所） 正 戸井 武司（中央大学）
}

Hiroyuki Hoshino, Toyota Central R\&D Labs., Inc., Nagakute, Aichi 480-1192

Takeshi Toi, Chuo University, 1-13-27, Kasuga, Bunkyo-ku, Tokyo 112-8551

\begin{abstract}
This paper describes a large-scale automotive sound quality evaluation database created by the JSAE Sound Quality Evaluation Research Technical Committee. This database was created by conducting subjective evaluation tests under controlled conditions and using common procedures. It involves the subjective evaluation data for the interior sounds of accelerating gasoline passenger cars by 101 Japanese test subjects, and for the exterior sounds of diesel trucks at idle by 143 Japanese test subjects. Moreover, the subjects' profiles data (gender, age, sound quality specialists, and so on) are included. We can carry out various analyses on automotive sound quality and some effective results for improvements of sound quality can be obtained by using this database.
\end{abstract}

Key Words : Sound, Noise, Audition, Sound Quality, Subjective Rating

1.はじめに

自動車の音質は，レベル低減だけでなく質的な不快感の低 减, より快適な車内・車外音環境の実現, 他車との差別化な どの要求に伴い，近年ますます重要になってきている.

自動車の音質改善を効率的に行うには，人による評価（主 観量）だけでなく，計算機や計測器を用いた客観評価（物理 量）に基づいた改善指針の明確化が必要である。

人による評価では，個人差があり，特に一般の被験者が行 う場合，再現性，定量性が不十分である。これに対し，一定 の経験とトレーニングを積んだ専門被験者は, 評価語の共通 認識があり，評価の信頼性，再現性が高い(1)(2)。主観評価を 行う場合には主観評価法が重要となるが, 自動車の音質評価 に関しては，SD法がこれまでよく用いられており，いくつか の形容詞対を用いた評価事例がある (3)〜(6)．ただし，評価に個 人差があるため，できるだけ多くの被験者による評価が必要 である。

一方，計算機や計測器を用いた解析・客観評価（物理量） に関しては，物理的なレベルを表す物理量はほぼ共通化して きており，騒音レベル，音圧レベル，周波数スペクトル，オ クターブバンドレベル等が用いられているが，音質評価のた めの心理物理量はまだ固まっていない，しかしながら，最近 しばしば有効性が示される心理物理量として，ラウドネス， シャープネス, ラフネス等を挙げることができる ${ }^{(7) \sim(9)}$. 自動 車の音質評価において，このような各種物理量がどのような 主観量と対応するのかを明確にしていくことが重要と考え られる。

そこでまず，主観評価実験の実験手続きを標準化し，各機 関が独自に行うよりも大規模（被験者 100 名以上）で詳細解 析が可能な音質評価データベースを作成することにより，目 的に応じたいろいろな解析を行えるようにすることが必要 と考えられる. さらに，このデータベースを用いて，ラウド ネス等の標準的になりつつある心理物理量に関して，主観量 との関係を調べることによりその有効性を明らかにするこ とは，今後の音質改善において，共通的な知見として大いに 役立たせることができると考えられる.

このような立場に基つき, 2002 年度より自動車技術会音質
評価技術研究会（現音質評価技術部門委員会）においては， 以下の二点を目的として活動を行ってきた。

1. 代表的な手続きにより条件の統制された実験を行い, 主観量と物理量との関係解析等の詳細な解析に耐え うる大規模音質評価データベースを作成する。

2. 各種心理物理量の自動車の音質評価における有効性 を調査する。

本報告では，音質評価データベースの中味である音質評価 実験の詳細，主観評価結果，主観量と物理量との相関解析等 のいくつかの解析結果について述べる.

\section{2. 音質評価実験}

2. 1. 評価対象音の決定

音質評価技術研究会がまとめた自動車音源 CD のサンプル 音から適切な音源を選択・加工して，実験に用いることとし た(10).今回, 評価対象としたカテゴリは,「ガソリン乗用車 加速時車内音」と「ディーゼルトラックアイドル車外音」で ある，音質評価のためには，提示音にウインカ音等の異音の 混入していないことや，各種条件の統一が必要である。今回 は，以下の基淮を用いた。

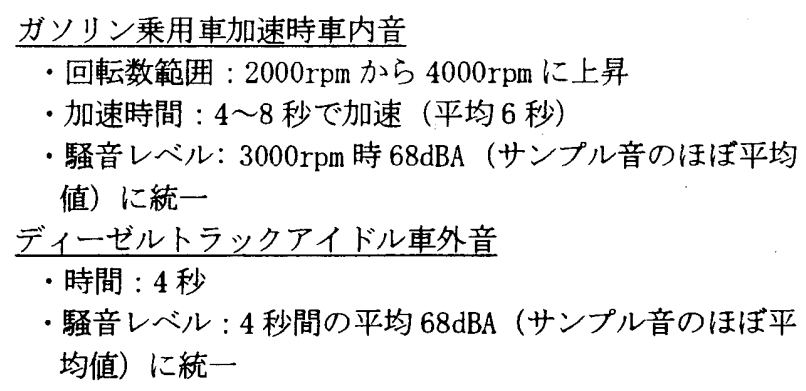

ガソリン乗用車加速音については 21 個, ディーゼルアイ ドル車外音については 13 個のサンプル音を選択し，上記条 件となるように音データを加工した．加速音は，理想的には

\footnotetext{
〔No04-10] 日本機械学会第 14 回環境工学総合シンポジウム 2004 講演論文集〔2004.7.12,13·東京〕
} 
加速時間も統一できるのが望ましいが，その場合には分析合 成等の技術が必要となる(11)，今回は収録時のままの加速時間 とした。

\section{2. 主観評価実験}

SD 法による主観評価実験を行った. これまでの研究事例に 基づき，自動車の音質評価に適すると考えられる形容詞対を 下記の通り選択した ${ }^{(1)(3) \sim(6)}$. 点線の下線は他方のカテゴリに はない形容詞対である，選択の考え方としては，総合的な印 象を表す形容詞対（不快な一快い，安っぽい一高級な）と， 美的・迫力・金属の音色三因子に対応する形容詞対が含まれ るようにした(1).

\section{ガソリン乗用車加速時車内音}

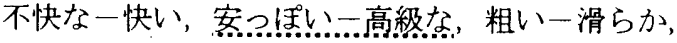

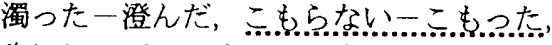

歯切れの悪い一歯切れの良い，落ち着いた一かん高い，

弱々しい一力強い, 重々しい一軽快な,

静かな一騒々しい，軟らかい一硬い

ディーゼルトラックアイドル車外音

不快な一快い, 粗い一滑らか,

濁った一澄んだ，衝撃的な...衝撃的でない!

歯切れの悪い一歯切れの良い, 落ち着いた一かん高い， 弱々しい一力強い，重々しい一軽快な，

静かな一騒々しい，軟らかい一硬い

評価方法としては，基準音を設定し，基準音に対して相対 的によ゙う感じるかを 7 段階 $(-3 \sim+3)$ で評価させた（図 1$)$.

繰り返し評価に関しては，実際には全ての評価音について 行うのが理想であるが，今回は評価音の数と評価語（形容詞 対）の数が多かったため，評価音のうちの 2 音のみ繰り返し 評価を行った。

音の提示方法は，一つの評価語に対して，基準音一評価音 の順に提示し，被験者は何度でも聞きなおせるようにした。

音の提示機材としては，パソコン，および，音質評価技術 研究会において推奨された（または同等の性能の）オーディ オインターフェイスとヘッドホンを用いた ${ }^{(12)}$.

被験者に関しては，性別，年代，音質関連従事者かどうか， 等の属性調查を行った。

\section{3. 主観評価結果}

図 2 に日本人による主観評価結果（加速時車内音 101 名，

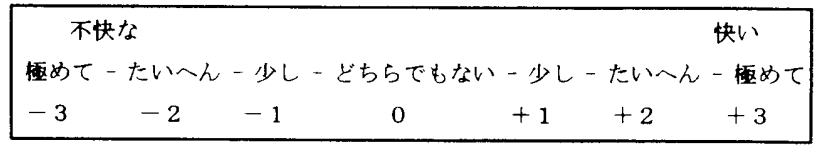

Fig.1. Seven-rank evaluation sample (for Japanese)

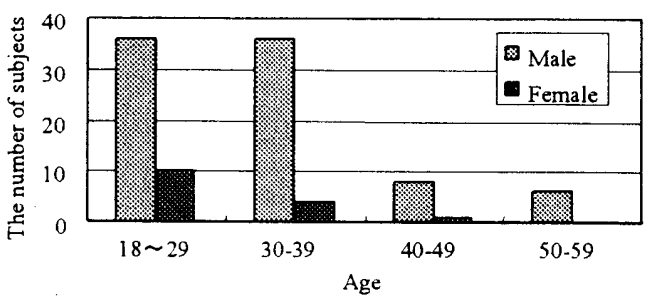

(a) Accelerating gasoline passenger cars $(\mathrm{n}=101)$

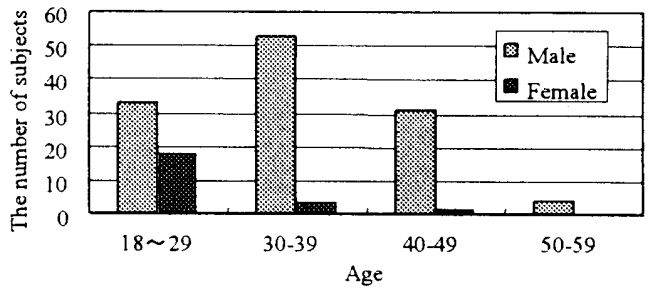

(b) Diesel trucks at idle ( $\mathrm{n}=143)$

Fig.2. Gender and age distribution of the test subjects

アイドル車外音 143 名）の男女別年代分布を示寸。結果とし て，30 歳代以下の男性が多く，女性がかなり少ないデータと なった．男女比や年代比はもう少し均等化できると理想的で ある、また，音質関連従事者は，加速時車内音では，男性 86 名中 67 名, 女性 15 名中 7 名, アイドル車外音では, 男性 121 名中 94 名，女性 22 名中 5 名であった.

表 1 (a)にガソリン乗用車加速時車内音, 表 1 (b)にディー ゼルトラックアイドル車外音の主観評価結果（全被験者の平 均值）を示す. 表中の ID は, 自動車音源 CD 中の音源 ID で ある. 表中の評価值は，值が十側に大きいほど 1 行目に示し た形容詞で示される感覚が基準音に対して大きいことを意 味する.

ここで，アイドル車外音の主観評価結果を見ると，「不快 な一快い「「粗い一滑らか」「落ち着いた一かん高い」など で，音による評価值の差が大きく，音質がかなり異なってい ることがわかる，それに対して，加速時車内音では音による 評価值の差はそれほど大きくない.

Table 1(a). Subjective evaluation results of the interior sounds for accelerating gasoline passenger cars (mean values for 101 test subjects)

\begin{tabular}{|c|c|c|c|c|c|c|c|c|c|c|c|}
\hline ID & $\begin{array}{c}\text { 快い } \\
\text { Pleasant }\end{array}$ & $\begin{array}{c}\text { 高級な } \\
\text { Expensive }\end{array}$ & $\begin{array}{l}\text { 滑らか } \\
\text { Smooth } \\
\end{array}$ & $\begin{array}{l}\text { 澄んだ } \\
\text { Clear }\end{array}$ & $\begin{array}{l}\text { こもった } \\
\text { Booming }\end{array}$ & $\begin{array}{c}\text { 歯切九の良い } \\
\text { Distinct }\end{array}$ & $\begin{array}{l}\text { かん高い } \\
\text { Shrill }\end{array}$ & $\begin{array}{l}\text { 力強い } \\
\text { Strong }\end{array}$ & $\begin{array}{l}\text { 軽快な } \\
\text { Light }\end{array}$ & $\begin{array}{l}\text { 騷々しい } \\
\text { Clamorous }\end{array}$ & $\begin{array}{l}\text { 硬い } \\
\text { Hard }\end{array}$ \\
\hline Wagon_2M (base) & 0 & 0 & 0 & 0 & 0 & 0 & 0 & 0 & 0 & 0 & 0 \\
\hline SUV_1M & 0.03 & -0.45 & -0.35 & 0.17 & -0.67 & 0.31 & 0.53 & -0.22 & 0.61 & 0.43 & 0.36 \\
\hline Sport_1M & 0.39 & 0.62 & 1.19 & 0.46 & 0.37 & 0.26 & -0.83 & -0.20 & 0.12 & -0.52 & -0.76 \\
\hline Sport_2M & 0.32 & -0.18 & -0.39 & 0.36 & -0.57 & 0.93 & 1.44 & 1.33 & 0.99 & 1.21 & 0.57 \\
\hline Sedan $5 \mathrm{M}$ & .0 .46 & -0.22 & -0.21 & -0.57 & 0.91 & -0.24 & -0.25 & 0.99 & -1.04 & 0.87 & 0.28 \\
\hline Sedan_6M & -0.02 & -0.19 & 0.20 & 0.32 & -0.35 & 0.32 & 0.20 & 0.04 & 0.40 & -0.03 & 0.05 \\
\hline Sedan_8M & 0.29 & -0.08 & 0.34 & 0.26 & -0.35 & 0.22 & 0.18 & -0.01 & 0.59 & -0.14 & 0.11 \\
\hline Sedan_11M & -0.51 & -0.53 & -0.58 & -0.22 & -0.50 & 0.10 & 0.94 & 0.42 & 0.27 & 1.05 & 0.50 \\
\hline Sedan_13M & -0.35 & -0.01 & .0 .14 & 0.04 & -0.14 & -0.07 & 0.44 & 0.26 & -0.01 & 0.57 & 0.21 \\
\hline Sedan_14M & -0.48 & -0.16 & -0.56 & -0.31 & 0.06 & -0.26 & 0.24 & 0.35 & -0.31 & 0.79 & 0.22 \\
\hline Sedan_15M & 0.84 & 0.60 & 0.73 & 0.69 & -0.76 & 0.08 & -0.40 & -0.87 & 0.81 & -0.90 & -0.86 \\
\hline Sedan_17M & -0.67 & -0.59 & -0.74 & -0.38 & -0.48 & -0.25 & 0.82 & 0.46 & 0.24 & 0.88 & 0.52 \\
\hline Sedan_18M & -0.13 & -0.14 & -0.22 & 0.12 & -0.76 & 0.04 & 0.77 & -0.26 & 0.82 & 0.17 & 0.32 \\
\hline Wagon_1M & -0.34 & -0.24 & -0.26 & -0.23 & 0.52 & 0.27 & 0.29 & 0.73 & -0.17 & 0.76 & 0.19 \\
\hline Wagon_5M & -0.66 & -0.13 & -0.15 & -0.44 & 0.92 & -0.30 & -0.15 & 0.61 & -0.64 & 0.75 & 0.25 \\
\hline Wagon_6M & -1.14 & -0.65 & -1.21 & -1.08 & 0.51 & -0.71 & 0.54 & 0.98 & -1.35 & 1.62 & 0.52 \\
\hline Hatchback_IM & -1.95 & -1.45 & -1.67 & -1.46 & 1.03 & -0.79 & 1.29 & 1.58 & -1.32 & 2.50 & 1.32 \\
\hline Hatchback_2M & -0.40 & -0.26 & -0.22 & 0.02 & -0.30 & 0.18 & 0.58 & 0.27 & 0.16 & 0.75 & 0.34 \\
\hline Hatchback_8M & 0.62 & -0.18 & 0.51 & 0.41 & -0.47 & 0.18 & -0.27 & -0.33 & 0.65 & -0.44 & -0.33 \\
\hline Hatchback_9M & -0.51 & -0.61 & -0.17 & -0.02 & -0.91 & -0.16 & 0.75 & -0.63 & 0.64 & 0.48 & 0.19 \\
\hline Hatchback $12 \mathrm{M}$ & -0.32 & -0.13 & -0.51 & -0.43 & -0.04 & 0.22 & 0.28 & 0.81 & -0.14 & 0.80 & 0.36 \\
\hline
\end{tabular}


Table 1(b). Subjective evaluation results of the exterior sounds of diesel trucks at idle (mean values for 143 test subjects)

\begin{tabular}{|c|c|c|c|c|c|c|c|c|c|c|}
\hline ID & $\begin{array}{c}\text { 仭い } \\
\text { Pleasant }\end{array}$ & $\begin{array}{l}\text { 滑らか } \\
\text { Smooth }\end{array}$ & $\begin{array}{l}\text { 澄んだ } \\
\text { Clear }\end{array}$ & $\begin{array}{l}\text { 䘖慗的な } \\
\text { Impulsive }\end{array}$ & $\begin{array}{c}\text { 鮆切れの良い } \\
\text { Distinct }\end{array}$ & $\begin{array}{c}\text { かん高い } \\
\text { Shrill }\end{array}$ & $\begin{array}{l}\text { 力強い } \\
\text { Strong }\end{array}$ & $\begin{array}{l}\text { 圣快な } \\
\text { Light }\end{array}$ & $\begin{array}{l}\text { 騒々しい } \\
\text { Clamorous }\end{array}$ & $\begin{array}{l}\text { 硬い } \\
\text { Hard }\end{array}$ \\
\hline M_truck_11M (base) & 0 & 0 & 0 & 0 & 0 & 0 & 0 & 0 & 0 & 0 \\
\hline L_truck_9M & -1.07 & -1.10 & -0.41 & -0.96 & 0.28 & 0.20 & 1.26 & -0.83 & 1.04 & 0.89 \\
\hline L_truck_10M & -0.88 & -1.13 & -0.14 & -0.92 & 0.49 & 0.38 & 0.76 & -0.14 & 0.97 & 1.06 \\
\hline $\mathrm{L}$ truck $11 \mathrm{M}$ & -0.65 & -0.54 & 0.15 & -0.40 & 0.57 & 1.01 & .0 .04 & 0.68 & 0.98 & 0.73 \\
\hline L truck $12 \mathrm{M}$ & -1.51 & -1.77 & -0.28 & -1.27 & 0.33 & 0.81 & 0.81 & -0.26 & 1.44 & 1.49 \\
\hline M_truck 9M & 0.17 & 0.45 & -0.11 & 0.58 & -0.13 & -0.25 & 0.21 & -0.12 & -0.08 & -0.20 \\
\hline $\mathrm{M}$ truck $10 \mathrm{M}$ & 0.86 & 0.78 & 0.82 & 1.01 & 0.37 & -0.21 & -1.02 & 0.94 & -0.93 & -0.53 \\
\hline H_truck_13M & -1.86 & -1.83 & -1.26 & -1.35 & -0.46 & 0.20 & 1.43 & -1.30 & 1.49 & 1.33 \\
\hline $\mathrm{H}$ truck $14 \mathrm{M}$ & -1.81 & -0.62 & -0.17 & -0.63 & -0.33 & 1.78 & 0.12 & 0.17 & 1.70 & 0.60 \\
\hline H_truck_15M & 0.03 & -0.33 & 0.49 & -0.08 & 0.56 & 0.68 & -0.12 & 0.77 & 0.47 & 0.59 \\
\hline $\mathrm{H}^{-}$truck $10 \mathrm{M}$ & -0.75 & -0.88 & -0.67 & -0.38 & .0 .59 & -0.11 & 0.58 & -0.84 & 0.61 & 0.43 \\
\hline $\mathrm{H}_{-}$truck_17M & -0.91 & -0.62 & 0.26 & -0.31 & 0.04 & 0.93 & 0.17 & 0.36 & 0.99 & 0.53 \\
\hline $\mathrm{H}$ truck $18 \mathrm{M}$ & -0.58 & -0.57 & -1.01 & -0.12 & .0 .92 & -0.46 & 0.68 & -1.07 & 0.49 & -0.07 \\
\hline
\end{tabular}

\section{3. 加速時車内音の各種解析結果}

この章では，ガソリン乗用車加速時車内音の主観評価結果 について解析を行った結果を示す。

\section{1. 解析に用いた物理量}

今回，物理量として，騒音レベルと，主観的印象と対応が 良いと報告されている下記の心理物理量を用いた(7)(8)。分析 值としては，音全体の平均値と時間ごとの分析值を算出した

・ラウドネス(Loudness)：音の大きさ（臨界帯域ごと）

・シャープネス(Sharpness)：音の鋭さ

・ラフネス(Roughness) : 音の粗さ

・変動強度 (Fluctuation strength) : $20 \mathrm{~Hz}$ 以下の変動

・調音性 (Tonality)：純音成分の相対的大きさ

なお，今回用いたサンプル音はバイノーラルヘッド(HATS: Head and Torso Simulator) による収録であるので，左右音 で騒音レベルが大きい方を分析值とした。

\section{2. 主観評価值と物理量との相関解析}

表 2 に, 主観評価值（101 名の平均值）と物理量（各評価 音の平均值）との相関解析結果を示す。「静かな一騒々しい」 は, ラウドネスと高い相関(相関係数 0.93)を示した(図 3 ).

また，「不快な一快い」「安っぽい一高級な」「粗い一滑 らか」「溜った一澄んだ」「軟らかい一硬いりについてもラ ウドネスとの相関係数 0.85 以上となった。弱々しい一力 強いりについては，ラウドネスよりも騒音レベルと高い相関 （相関係数 0.82）を示した.

全体的な傾向として，3000rpm 時の騒音レベルを統一した にもかかわらず，音全体のラウドネスがかなり異なったため， 評価がラウドネスに引つ張られる結果になったと考えられ る.

\section{3. 解析詨象音の限定}

全体的にラウドネス依存の評価結果になっていることを 考慮し，ラウドネス 18〜22sone の音（10 個）に限定して相 関解析を行った，結果を表 3 に示す. 表 2 で相関係数が 0.8 以下であった評価語を斜体文字で示した。「こもらないーこ もった」「落ち着いた一かん高い」についてはシャープネス と相関係数 0.8 以上となった.シャープネスと「落ち着いた 一かん高い」の評価との関係を図 4 に示す.

さらに, シャープネスが「安っぽい一高級な」「重々しい 一軽快な」の評価に影響していることも示唆された。

\section{4. 被験者属性ごとの因子分析}

被験者の属性で興味深い点の一つは，音質関連従事者かど うかで評価傾向がどのように異なるかという点である．そこ で，音質関連従事者グループと音質関連従事者でないグルー プについて因子分析を行った。結果を表 4 に示す.
Table 2. Correlation coefficients between subjective ratings and objective ratings

\begin{tabular}{lcccccc}
\hline & $\begin{array}{c}\text { SPL } \\
(\mathrm{dBA})\end{array}$ & $\begin{array}{c}\text { ISO532B } \\
\text { Loudness } \\
\text { (sone) }\end{array}$ & $\begin{array}{c}\text { Sharpness } \\
\text { (acum) }\end{array}$ & $\begin{array}{c}\text { Roughness } \\
\text { (asper) }\end{array}$ & $\begin{array}{c}\text { Fluctuation } \\
\text { Strength } \\
\text { (vacil) }\end{array}$ & $\begin{array}{c}\text { Tonality } \\
\text { (tu) }\end{array}$ \\
\hline Pleasant & -0.71 & -0.89 & -0.19 & -0.39 & -0.38 & -0.09 \\
Exponsive & -0.74 & -0.87 & -0.44 & -0.56 & -0.33 & -0.02 \\
Smooth & -0.79 & -0.89 & -0.37 & -0.50 & -0.15 & 0.20 \\
Clear & -0.71 & -0.87 & -0.04 & -0.36 & -0.26 & -0.09 \\
Booming & 0.50 & 0.48 & -0.56 & -0.15 & 0.32 & 0.51 \\
Dist inct & -0.28 & -0.57 & -0.04 & -0.24 & -0.29 & -0.08 \\
Shrill & 0.61 & 0.66 & 0.68 & 0.46 & 0.10 & -0.26 \\
Strong & 0.82 & 0.75 & -0.12 & 0.20 & 0.18 & 0.16 \\
Light & -0.53 & -0.65 & 0.29 & -0.04 & -0.23 & -0.27 \\
Clamorous & 0.88 & 0.93 & 0.28 & 0.36 & 0.20 & 0.04 \\
Hard & 0.82 & 0.86 & 0.35 & 0.46 & 0.31 & -0.07 \\
\hline
\end{tabular}

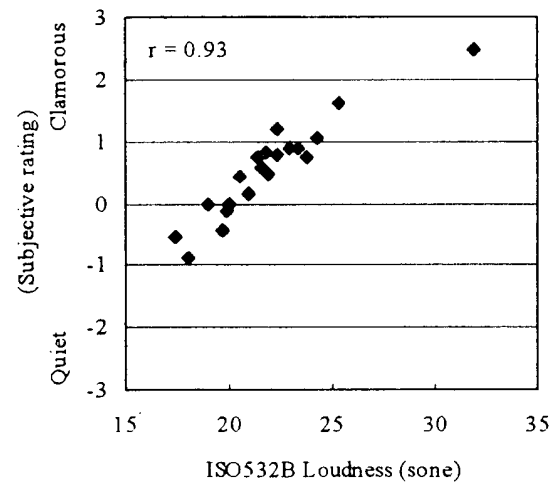

Fig.3. Relation between loudness and "Quiet/Clamorous"

Table 3. Correlation coefficients between subjective ratings and objective ratings (Evaluation sounds with loudness of between 18 and 22 sone)

\begin{tabular}{lcccccc}
\hline & $\begin{array}{c}\text { SPL } \\
\text { (dBA) }\end{array}$ & $\begin{array}{c}\text { ISO532B } \\
\text { Loudness } \\
\text { (sone) }\end{array}$ & $\begin{array}{c}\text { Sharpness } \\
\text { (acum) }\end{array}$ & $\begin{array}{c}\text { Roughness } \\
\text { (asper) }\end{array}$ & $\begin{array}{c}\text { Fluctuation } \\
\text { Strength } \\
\text { (vacil) }\end{array}$ & $\begin{array}{c}\text { Tonality } \\
\text { (tu) }\end{array}$ \\
\hline Pleasant & -0.47 & -0.75 & -0.07 & 0.24 & 0.14 & 0.24 \\
Expensive & 0.00 & -0.23 & -0.71 & -0.35 & 0.40 & 0.22 \\
Smooth & -0.51 & -0.75 & -0.23 & 0.11 & 0.36 & 0.56 \\
Clear & -0.68 & -0.73 & 0.30 & 0.28 & 0.48 & 0.16 \\
Booming & 0.64 & 0.11 & -0.83 & -0.62 & -0.02 & 0.41 \\
Distinct & -0.38 & -0.59 & 0.03 & 0.39 & -0.05 & -0.39 \\
Shrill & -0.25 & 0.46 & 0.82 & 0.36 & 0.09 & -0.65 \\
Strong & 0.54 & 0.27 & -0.68 & -0.29 & -0.15 & -0.09 \\
Light & -0.73 & -0.41 & 0.71 & 0.61 & 0.17 & -0.25 \\
Clamorous & 0.68 & 0.84 & 0.05 & -0.20 & -0.28 & -0.31 \\
Hard & 0.36 & 0.64 & 0.23 & -0.05 & -0.08 & -0.59 \\
\hline
\end{tabular}


結果から，二つのグループで評価傾向はかなり異なること がわかる，音質関連従事者グループでは，第 1 因子は「かん 高さ・美的」因子，第 2 因子は「歯切れ・軽快」因子，第 3 因子は「迫力」因子，また，音質関連従事者でないグループ では，それぞれ「美的・快適性」因子，「かん高さ」因子， 「雬切れ」因子のように解䣋することができる。

\section{5. 属性別の主観量と物理量の相関}

被験者の属性別に主観量と物理量の相関を調べた。その結 果，例えば，「こもらなーこもった」と $200 \mathrm{~Hz}$ 以下ラウド ネスとの相関係数は, 音質関連従事者グループで 0.79 , 音質 関連従事者でないグループで 0.18 と大きく異なった。この 結果は, 音質関連従事者でない被験者では,「こもった」と いう形容詞と音の物理的な特徴との対応付け（意味の理解, 聴感）が難しいことを示唆している。

\section{4. おわりに}

今回作成した音質評価データベースの中味である音質評 価実験の詳細と, 本データベースを用いたガソリン乗用車加 速時車内音に関する主観量物理量相関解析結果，および，い くつかの解析結果について述べた。結果を以下にまとめる.

1. 実験手続きを下記のように標準化し, 主観評価結果を データベース化した。

・音の選択基準を設定し，各種条件を統一

・基準音に対する相対評価

・被験者属性を調查

・推奨オーディオインターフェイスとヘッドホン による音の提示

2. 主観量物理量相関解析により,ガソリン乗用車加速時 車内音に対するラウドネス・シャープネスの有効性が 示された。

3. 本データベースにより，被験者属性ごとの因子分析の ような解析が可能であり，より詳細な結果が得られる ことが確認できた。

本報告では，日本人による評価データに関して述べたが， 海外での主観評価デー夕も 100 名規模でのデータベース化を 進めている ${ }^{(13)}$. 今後，各機関が共通に使える，汎用的で大規 模な音質評価データベースとしてまとめていく予定である.

\section{参考文献}

（1）難波精一郎：音色の測定・評価法と乙の適用例，東京， 忘用技術出版，（1992）

（2）星野博之, 小沢義彦：自動車の音質評価実験法, 自動車 技術, Vol. 57, No. 7, p. 94-98 (2003)

（3）岸篤秀, 畑秀二: 自動車車室内音音質評価手法について, 自動車技術，Vol. 40, No. 4, p. 464-470（1986）

（4）石山武，荒井紀博：車内騒音フィーリングの評価に関す る一考察, 自動車研究, Vol. 8, No. 5, p. 164-167 (1986)

(5) 高尾秀男, 橋本竹夫：乗用車走行時の車内音の主観評価 一その $1 \mathrm{SD}$ 法による音質評価形容詞対の選択一，自動車技 術会学術講演会前刷集, No. 882, p. 467-470（1988）

（6）山下㓮，石井康夫，中村光男，北村音一：自動車車室内 音の音色評価について，日本ゴム協会誌，Vol.63，No. 3, p. 42-50 (1990)

（7）大橋正尚ほか：音質評価を評価するためのパラメータと 計測システム, 自動車技術会学術講演会前刷集, No. 981, p. 101-104 (1998)

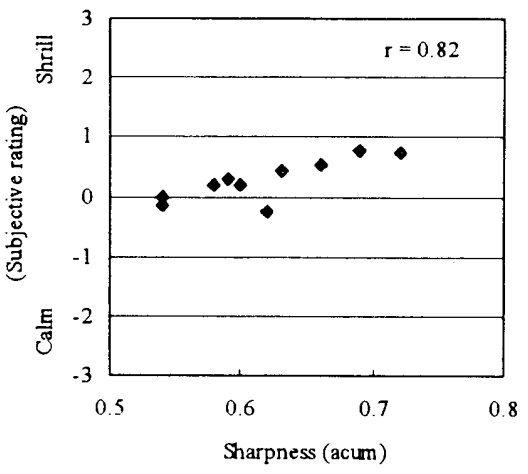

Fig.4. Relation between sharpness and "Calm/Shrill" (Evaluation sounds with loudness of between 18 and 22 sone)

Table 4. Factor analysis results (sound quality specialists and non-specialists)

(a) Specialists of sound quality ( $\mathrm{N}=74)$

\begin{tabular}{lcccc}
\hline & Factor 1 & Factor 2 & Factor 3 \\
Pleasant & -0.546 & 0.733 & -0.301 \\
Expensive & -0.81 & 0.46 & -0.113 \\
Smooth & -0.839 & 0.40 .9 & -0.255 \\
Clear & -0.508 & 0.721 & -0.445 \\
Booming & 0.033 & -0.584 & 0.739 \\
Distinct & -0.179 & 0.935 & -0.121 \\
Shrill & 0.983 & 0.133 & -0.006 \\
Strong & 0.469 & -0.181 & 0.846 \\
Light & -0.051 & 0.813 & -0.569 \\
Clamorous & 0.772 & -0.403 & 0.47 \\
Hard & 0.882 & -0.227 & 0.322 \\
\hline Contribution & 41.0 & 32.5 & 20.8 \\
ratio (\%) & & & \\
\hline
\end{tabular}

(b) Non-specialists of sound quality $(\mathrm{N}=27)$

\begin{tabular}{lrrrr}
\hline & Factor 1 & Factor 2 & Factor 3 \\
Pleasant & 0.687 & -0.381 & 0.587 \\
Expensive & 0.387 & -0.648 & 0.381 \\
Smooth & 0.717 & -0.44 & 0.515 \\
Clear & 0.727 & -0.008 & 0.611 \\
Booming & -0.165 & -0.879 & -0.046 \\
Distinct & -0.001 & 0.008 & 0.909 \\
Shrill & -0.441 & 0.837 & 0.012 \\
Strong & -0.919 & 0.138 & 0.19 \\
Light & 0.814 & 0.351 & 0.322 \\
Clamorous & -0.908 & 0.353 & -0.155 \\
Hard & -0.741 & 0.527 & -0.244 \\
\hline Contribution & & & \\
ratio (\%) & 43.3 & 25.2 & 19.8 \\
\hline
\end{tabular}

(8) E. Zwicker \& H. Fast1 : Psychoacoustics Facts and Models, Springer-Verlag, New York, (1999)

（9）星野博之，加藤裕康：官能評価構造に基づいた風切り音 の総合評価法, 自動車技術会学術講演会, No. 112-00, p. 9-12, (2000)

（10）戸井武司：自動車音サンプルの収集と CD 化，自動車技 術会音質フォーラムテキスト， p. 3-6，（2002）

（11）前田修：エンジン音のリアルタイム合成法, 自動車技 術会振動騒音フォーラムテキスト， p. 29-34，（2001）

（12）前田修ほか：音質評価のための音再生装置と簡易校正 装置, 自動車技術会振動騒音フォーラムテキスト，p. 23-27， (2004)

（13）戸井武司ほか：音質評価の国際比較に対する考察，自 動車技術会振動騒音フォーラムテキスト，p. 33-39，（2004） 